\title{
Effect of Excess L-Lysine on Rat Growth and on Plasma and Tissue Concentrations of Copper, Iron and Zinc
}

\author{
G. Vaughan Mitchell and M. Young JENKINS \\ Division of Nutrition, Food and Drug Administration, \\ Washington, DC 20204, U.S.A.
}

(Received April 1, 1983)

\begin{abstract}
Summary A 28-day feeding study was conducted to test the effect of excess dietary lysine on rat growth and the concentration of copper, iron and zinc in plasma and liver. Young male Sprague-Dawley rats were fed a $10 \%$ protein casein diet with or without excess lysine. There were no significant differences in body weight gain, food intake or plasma proteins among the dietary treatment groups. Supplementation of the basal diet with $2.1 \%$ L-lysine caused a $53 \%$ reduction in hepatic copper and a significant reduction in hepatic iron. The addition of $0.7 \%$ or $2.1 \%$ lysine to the basal diet caused significant reductions in levels of plasma copper. The $2.1 \%$ level of lysine tended to lower the concentration of zinc in plasma. The data suggest that lysine may interfere with the availability of selected minerals by reducing tissue utilization or promoting excretion, or both.
\end{abstract}

Key Words lysine, copper, iron, zinc, rat growth, plasma proteins

The existence of a nutritional interaction between amino acids and minerals has been shown $(1,2)$. Several reports have suggested that amino acids influence the absorption and excretion of minerals (3-7). Histidine, cysteine and lysine enhanced iron uptake and absorption(5). Increased concentrations of cysteine and histidine in serum and urine were found to be associated with increased urinary zinc excretion (8). Tyrala et al. (9) reported that urinary copper losses in infants receiving free amino acid solutions were positively correlated with the excretion of glycine, methionine, histidine and lysine. Giroux and Prakash(10) studied the influence of various salts and chelates of zinc given by gavage on serum zinc levels of rats. They found that zinc sulfate-liquid mixtures of the amino acids lysine, cysteine, glycine and histidine produced higher levels of serum zinc than an equivalent dosage $(10 \mathrm{mg} / \mathrm{kg})$ of zinc sulfate alone. On the other hand, one report has indicated that an excessive amount of histidine had an adverse effect on the absorption of selected minerals (6).

The formation of amino acid-mineral complexes has been proposed as one of the reasons for the amino acid-induced changes in mineral uptake, absorption and excretion $(4,6,7)$. This postulate suggests that the possible consequences of ex- 
cessive supplementation of diets with some amino acids may be alterations in mineral storage in the body. The present study was undertaken to examine the effect of excess lysine supplementation on rat growth and the iron, copper and zinc content of plasma and liver. This study was partly motivated by the increased human consumption of concentrated lysine supplements and concern for potential adverse effects on health due to moderately excessive levels of dietary lysine.

\section{METHODS}

Male weanling Sprague-Dawley rats (Harlan Sprague-Dawley, Madison, Wisconsin), 22 days old and weighing $46-67 \mathrm{~g}$, were used. The rats were individually housed in suspended stainless steel cages in a temperature-controlled $\left(22 \pm 2{ }^{\circ} \mathrm{C}\right)$ room operated on a 12-h light-dark cycle. The animals were fed a commercial rat chow (Ralston Purina Co., St. Louis, Missouri) ad libitum for 7 days. At the end of the 7 days, the rats were reweighed and those with weights at the extremes of the weight distribution curve were discarded. Of the remaining animals, 30 rats weighing 99-113 g were randomly assigned to the three dietary treatments (10 rats per group): casein basal, casein basal $+0.7 \% \mathrm{~L}$-lysine or casein basal $+2.1 \% \mathrm{~L}$-lysine.

The composition of the casein basal diet, which contained $10 \%$ protein, is shown in Table 1. According to the label claim, the mineral mix supplied 6.5, 37.2 and $17.1 \mu \mathrm{g}$ copper, iron and zinc/g diet, respectively. All experimental diets and distilled water were provided ad libitum for the 28-day feeding period. Food con-

Table 1. Composition of the basal diet. ${ }^{a}$

\begin{tabular}{lc}
\hline \multicolumn{1}{c}{ Ingredient } & $\mathrm{g} / 100 \mathrm{~g}$ diet \\
\hline ANRC casein $^{\mathrm{b}}$ & 11.43 \\
Bernhart-Tomarelli mineral $\mathrm{mix}^{\mathrm{c}}$ & 4.00 \\
AIN vitamin mix $76^{\mathrm{d}}$ & 1.00 \\
Cellulose & 5.00 \\
Corn oil & 5.00 \\
Choline bitartrate & 0.20 \\
Selenium and chromium mix & 0.10 \\
Sucrose : cornstarch $(2: 1)$ & 73.27 \\
\hline
\end{tabular}

${ }^{a} \mathrm{~L}$-Lysine monohydrochloride was added to the basal diet at the expense of the sucrosecornstarch mix to form the basal $+0.7 \%$ lysine and basal $+2.1 \%$ lysine diets. ${ }^{b}$ Reference protein contained $87.5 \%$ protein; purchased from Humko Sheffield Chemical Co., Lyndhurst, New Jersey. ${ }^{\circ}$ Contained the following (g/ $\mathrm{kg}$ diet): calcium carbonate, 0.84 ; calcium phosphate, 29.4; citric acid, 0.09 ; cupric citrate, 0.02 ; ferric citrate $\cdot 5 \mathrm{H}_{2} \mathrm{O}, 0.22$; magnesium oxide, 1.0; manganese citrate, 0.34 ; potassium iodide, 0.0004 ; potassium phosphate dibasic, 3.24 ; potassium sulfate, 2.72 ; sodium chloride, 1.22 ; sodium phosphate, 0.86; zinc citrate $\cdot 2 \mathrm{H}_{2} \mathrm{O}, 0.05$. ${ }^{\mathrm{d}} \mathrm{ICN}$ Pharmaceuticals, Cleveland, Ohio. ${ }^{\mathrm{e}}$ Provided 0.1 and $0.3 \mathrm{mg}$ selenium and chromium $/ \mathrm{kg}$ diet, respectively. 
sumption and animal weights were recorded weekly.

At the end of the 28-day feeding period, the rats were killed by carbon dioxide asphyxiation and blood was drawn by heart puncture using a heparinized syringe. The spleen, liver and kidneys were excised and weighed. The liver, spleen and plasma samples were stored at $-15^{\circ} \mathrm{C}$ until analyzed.

All glass and plastic ware was washed before use with $20 \% \mathrm{HCl}$ and deionized distilled water to minimize contamination. All solutions were prepared in deionized distilled water, and reagent grade chemicals were used. Total protein and albumin were determined using an Ames blood analyzer (Ames Division, Miles Laboratories, Inc., Elkhart, Indiana).

Spleen and liver samples were wet-digested in a mixture of concentrated nitric acid and $70 \%$ perchloric acid $(5: 1, \mathrm{v} / \mathrm{v})$. Standards were prepared using the same matrix as with the digested samples. The copper, zinc and iron contents of tissues were determined using flame atomic absorption spectrophotometry (AAS) (Model 503, Perkin-Elmer Corp., Norwalk, Connecticut). Plasma zinc, iron and copper were determined in diluted plasma using AAS (11).

Data were evaluated using an analysis of variance (ANOVA). Individual means were then compared using Ducan's multiple range test (12). Unless otherwise noted, statistical significance is $p \leq 0.05$.

\section{RESULTS AND DISCUSSION}

After 28 days on the experimental diets, no significant differences in weight gain, food intake or food efficiency were detected among the different treatment groups (Table 2). The mean weight gains of the three groups ranged from 100 to $104 \mathrm{~g}$. Excessive intakes of individual amino acids in young animals fed a low-

Table 2. Effect of excess lysine on weight gain, food intake and organ weight. ${ }^{a}$

\begin{tabular}{lccc}
\hline \multicolumn{1}{c}{ Measurement } & Basal & $\begin{array}{c}\text { Basal }+0.7 \% \\
\text { lysine }\end{array}$ & $\begin{array}{c}\text { Basal }+2.1 \% \\
\text { lysine }\end{array}$ \\
\hline Initial body wt. (g) & $106 \pm 1.5$ & $107 \pm 1.2$ & $106 \pm 1.2$ \\
Weight gain (g) & $100 \pm 5.2$ & $103 \pm 5.2$ & $104 \pm 6.1$ \\
Food intake (g/28 days) & $426 \pm 12.1$ & $431 \pm 19.1$ & $417 \pm 23.3$ \\
Food efficiency (g gained/g food) & $0.23 \pm 0.01$ & $0.24 \pm 0.01$ & $0.25 \pm 0.01$ \\
Liver wt. (g) & $8.69 \pm 0.19$ & $9.06 \pm 0.37$ & $8.66 \pm 0.26$ \\
(g/100 g body wt.) & $4.21 \pm 0.04$ & $4.31 \pm 0.10$ & $4.11 \pm 0.10$ \\
Spleen wt. (g) & $0.44 \pm 0.01$ & $0.44 \pm 0.02$ & $0.44 \pm 0.01$ \\
(g/100 g body wt.) & $0.21 \pm 0.01$ & $0.21 \pm 0.01$ & $0.21 \pm 0.01$ \\
Kidney wt. (g) & $1.43 \pm 0.04$ & $1.46 \pm 0.04$ & $1.54 \pm 0.03$ \\
(g/100 g body wt.) & $0.69 \pm 0.01$ & $0.70 \pm 0.01$ & $0.73 \pm 0.01$ b \\
\hline
\end{tabular}

${ }^{a}$ Values are the mean \pm SEM of 10 rats per group. ${ }^{b}$ Significantly different $(p \leq 0.05)$ from basal and basal $+0.7 \%$ lysine groups. 
Table 3. Effect of excess lysine on plasma proteins. ${ }^{a}$

\begin{tabular}{lccc}
\hline $\begin{array}{c}\text { Protein } \\
(\mathrm{mg} / 100 \mathrm{ml})\end{array}$ & Basal & $\begin{array}{c}\text { Basal }+0.7 \% \\
\text { lysine }\end{array}$ & $\begin{array}{c}\text { Basal }+2.1 \% \\
\text { lysine }\end{array}$ \\
\hline Total protein & $6.6 \pm 0.09$ & $6.6 \pm 0.12$ & $6.5 \pm 0.11$ \\
Albumin & $2.8 \pm 0.12$ & $2.9 \pm 0.12$ & $2.9 \pm 0.06$ \\
Globulin & $3.8 \pm 0.13$ & $3.7 \pm 0.15$ & $3.6 \pm 0.11$ \\
Albumin/globulin ratio & $0.75 \pm 0.05$ & $0.81 \pm 0.05$ & $0.81 \pm 0.03$ \\
\hline
\end{tabular}

${ }^{a}$ Values are the mean \pm SEM of 10 rats per group.

protein diet can result in adverse effects ranging from moderate growth and food intake depression to the development of pathologic lesions and low survival rates (13). Excess lysine has a more moderate effect on growth. Levels of lysine in excess of $3 \%$ of the diet are generally required to produce depression of growth and food intake $(14,15)$. The results presented here indicate that a lysine level as high as $2.1 \%$ of the diet died not affect food intake or growth.

The kidney weights of the rats fed $2.1 \%$ lysine tended $(p=0.10)$ to be higher than those of the other groups. Relative kidney weights of the rats fed $2.1 \%$ lysine were significantly higher $(p \leq 0.05)$ than those of the other two treatment groups (Table 2). No significant differences were found in liver and spleen weights or relative weights of these organs among the treatments. The effect of lysine on kidney weight in this study was consistent with results obtained in studies in which the kidneys were enlarged by feeding excess amounts of other essential amino acids (13). Oral or intravenous administration of amino acids or high protein diets significantly increased renal flow and glomerular filtration rates in dogs (16). Brenner et al. (17) suggested that the mechanism responsible for these increases was also responsible for the sustained hyperfiltration and accompanying renal hypertrophy, and that some circulating hormone or intermediate effector might be responsible for the increased renal perfusion and filtration induced by protein-rich (amino acid) meals.

The effect of lysine on the concentration of plasma protein is shown in Table 3. Excess lysine did not cause any significant differences in total protein, albumin, globulin or the albumin-globulin ratio when compared with rats fed on the basal diet. Alterations in the individual globulin fractions may have occurred without a significant change in the total fraction. However, we do not have data on the individual fractions.

Hepatic and plasma concentrations of copper, zinc and iron are shown in Table 4. The data clearly indicate that excess lysine affects copper storage. The concentration of hepatic copper in rats fed $2.1 \%$ lysine was significantly lower $(p \leq 0.05)$ than in rats fed the basal diet or the basal diet plus $0.7 \%$ lysine. Hepatic copper was reduced by $53 \%$ in rats fed $2.1 \%$ lysine compared to rats fed the basal diet.

Fasting animals absorb copper from copper sulfate considerably faster than from copper complexes (18). However, when food is given with the copper 
Table 4. Effect of excess lysine on minerals in liver, plasma and spleen.

\begin{tabular}{|c|c|c|c|}
\hline Mineral & Basal & $\begin{array}{l}\text { Basal }+0.7 \% \\
\text { lysine }\end{array}$ & $\begin{array}{c}\text { Basal }+2.1 \% \\
\text { lysine }\end{array}$ \\
\hline \multicolumn{4}{|c|}{$\operatorname{Liver}^{\mathbf{a}}(\mu \mathrm{g} / \mathrm{g}$ wet tissue $)$} \\
\hline Copper & $12.6 \pm 2.3$ & $10.4 \pm 1.8$ & $5.9 \pm 1.0^{\mathrm{b}}$ \\
\hline Iron & $38.4 \pm 1.8$ & $39.6 \pm 2.4$ & $30.6 \pm 1.6^{\mathrm{b}}$ \\
\hline Zinc & $29.4 \pm 0.8$ & $26.6 \pm 1.0$ & $27.2 \pm 0.9$ \\
\hline \multicolumn{4}{|c|}{$\operatorname{Plasma}^{c}(\mu \mathrm{g} / 100 \mathrm{ml})$} \\
\hline Copper & $163.4 \pm 5.5^{\mathrm{d}}$ & $127.5 \pm 7.5$ & $142.1 \pm 4.4$ \\
\hline Iron & $330.5 \pm 22.4$ & $369.8 \pm 41.7$ & $321.3 \pm 32.7$ \\
\hline Zinc & $255.3 \pm 43.4$ & $235.5 \pm 29.3$ & $143.0 \pm 18.6^{\mathrm{b}, \mathrm{e}}$ \\
\hline \multicolumn{4}{|c|}{ Spleen $^{\mathrm{a}}(\mu \mathrm{g} / \mathrm{g}$ wet tissue $)$} \\
\hline Iron & $109.4 \pm 9.0$ & $126.4 \pm 8.1$ & $128.0 \pm 5.6$ \\
\hline
\end{tabular}

preparations, the opposite effect occurs. High concentrations of copper-binding substances in the intestinal tract may lead to the formation of macromolecular compounds with the soluble copper present in the food, and the rate of copper diffusion is thereby considerably reduced (7). Kirchgessner and Grassmann (7) also reported that, when copper-amino acid complexes were fed to rats receiving a ration low in copper, storage of copper in the liver increased compared with a copper sulfate supplement. The copper content of the liver diminished with increased polymerization of the amino acid. A comparison of these studies with the results presented here is difficult since general experimental conditions were different and preformed copper-amino acid chelates were used in the earlier study.

The plasma levels of copper in rats fed $0.7 \%$ and $2.1 \%$ lysine were also significantly lower than those in rats fed the basal diet. In normal mammals, about $90 \%$ of the plasma copper exists as ceruloplasmin, and there is a highly significant correlation between ceruloplasmin levels and plasma copper levels (19). The significant reductions in plasma copper in the present study suggest the possibility of reduced levels of ceruloplasmin.

The biochemical basis for the reduced plasma and hepatic concentrations of copper in the rats fed the highest level of lysine is unclear. Our results suggest that, at least in part, excess lysine interferes with the availability of copper by reducing Vol. 29, No. 6, 1983 
tissue utilization or promoting copper excretion, or both. Proteins or their breakdown products in the gastrointestinal tract play an important part in the dynamics of copper absorption and utilization(7). Tyrala et al.(9) suggested that elevated plasma amino acid concentrations, seen in infants receiving total parenteral alimentation, may promote increased urinary excretion of the copper-amino acid complexes and cause chronic losses of copper in the urine. They suggest that this phenomenon may contribute to copper depletion and the development of a copper deficiency syndrome in infants receiving long-term parenteral nutrition.

The liver iron concentration in rats fed $2.1 \%$ lysine was significantly lower $(p \leq 0.05)$ than in the other dietary treatment groups (Table 4). However, $2.1 \%$ lysine did not cause any significant alterations in plasma or spleen iron levels. No significant changes in plasma, liver and spleen iron levels occurred with $0.7 \%$ lysine. Earlier work (20) using rats that were fasted before sacrifice indicated that $2.1 \%$ lysine reduced spleen iron.

Lysine has been shown to enhance iron absorption by ligated intestinal loops (5). Conley and Hathcock (21), on the other hand, carried out in vivo studies which indicated that $0.3 \%$ histidine and $0.8 \%$ lysine added to a $10 \%$ casein diet did not significantly affect any of the indicators used to measure iron availability. Iron absorption and retention were not measured. The significance of the reduced liver stores found in the present study will require further elucidation. The fact that $2.1 \%$ lysine did not affect either plasma or spleen iron levels would suggest that excess lysine did not directly affect the absorption of iron.

No significant difference in liver zinc was detected among the dietary treatment groups. The level of plasma zinc was lower in the rats fed $2.1 \%$ lysine. One of the rats fed the $2.1 \%$ lysine diet had a plasma zinc level of $358 \mu \mathrm{g} / 100 \mathrm{ml}$; this accounted for part of the variability within this group. When the average value, $169.9 \pm$ $31.3 \mu \mathrm{g} / 100 \mathrm{ml}$, was corrected for this outlier, the group's plasma zinc level was significantly lower than with the other treatment groups $(p \leq 0.05)$.

The data presented here provide additional evidence of the interaction between amino acids and minerals. Whether the effects of excess lysine on copper and iron metabolism seen here can have a significant impact on the mineral status of humans is not known. Further work is necessary for a better understanding of the interrelationship between lysine and minerals.

The authors thank Benjamin Glasco for his technical assistance.

\section{REFERENCES}

1) Longton, R. W. (1978): Effect of nutrient toxicities in animals and man, amino acids, in CRC Handbook Series in Nutrition and Food, Section E: Nutritional Disorders, ed. by Rechcigl, M., CRC Press, West Palm Beach, Florida, pp. 447-484.

2) Shah, B. G. (1981): Chelating agents and bioavailability of minerals. Nutr. Res., 1, 617621.

3) Martinez-Torres, C., Romano, E., and Layrisse, M. (1981): Effect of cysteine on iron 
absorption in man. Am. J. Clin. Nutr., 34, 322-327.

4) Kroe, D., Kinney, T. D., Kaufman, N., and Klavins, J. V. (1963): The influence of amino acids on iron absorption. Blood, 21, 546-552.

5) Van Campen, D., and Gross, E. (1969): Effect of histidine and certain other amino acids on the absorption of iron-59 by rats. J. Nutr., 99, 68-74.

6) Forth, W., Nell, G., and Rummel, W. (1973): Chelating agents and the transfer of heavy metals across the mucosal epithelium, in Proceedings of the 7th Annual Conference on Trace Substances in Environmental Health, ed. by Hemphill, D. D., University of Missouri Press, Columbia, Missouri, pp. 339-345.

7) Kirchgessner, M., and Grassmann, E. (1970): The dynamics of copper absorption, in Proceedings of the World Association for Animal Production/International Biological Programme International Symposium on Trace Element Metabolism in Animals, ed. by Mills, C. F., E. and S. Livingstone, Edinburgh, pp. 277-287.

8) Lindeman, R. D., Baxter, D. J., Yunice, A. A., King, R. W., and Kraikit, S. (1977): Zinc metabolism in renal disease and renal control of zinc excretion, in Progress in Clinical and Biological Research, Zinc Metabolism: Current Aspects of Health and Disease, ed. by Brewer, G., and Prasad, A., Alan R. Liss, Inc., New York, pp. 193-208.

9) Tyrala, E. E., Brodsky, N. L., and Auerbach, V. H. (1982): Urinary copper losses in infants receiving free amino acid solutions. Am. J. Clin. Nutr., 35, 542-545.

10) Giroux, E., and Prakash, N. J. (1977): Influence of zinc-ligand mixtures on serum zinc levels in rats. J. Pharm. Sci., 66, 391-395.

11) Analytical Methods for Atomic Absorption Spectrophotometry (1982), Perkin-Elmer Corp., Norwalk, Connecticut.

12) Steele, R. G., and Torrie, J. H. (1960): Principles and Procedures of Statistics, McGrawHill, New York.

13) Harper, A. E., Benevenga, N. J., and Wohlhuster, R. M. (1970): Effects of ingestion of disproportionate amounts of amino acids. Physiol. Rev., 50, 428-558.

14) Muramatsu, K., Odagiri, H., Morishita, S., and Takeuchi, H. (1971): Effect of excess levels of individual amino acids on growth of rats fed casein diets. J. Nutr., 101, 11171126.

15) Sauberlich, H. E. (1961): Studies on the toxicity and antagonism of amino acids for weanling rats. $J$. Nutr., 75, 61-72.

16) Pitts, R. F. (1974): The effects of infusing glycine and of varying the dietary protein intake on renal hemodynamics in the dog. Am. J. Physiol., 142, 355-365.

17) Brenner, B. M., Meyer, T. W., and Hostetter, T. H. (1982): Dietary protein intake and progressive nature of kidney disease. N. Engl. J. Med., 299, 652-659.

18) Kirchgessner, M., and Weser, U. (1965): The dynamics of copper absorption. IV. Complex stability and copper absorption. Z. Tierphysiol. Tierernaehr. Futtermittelkd., 20, 44-49.

19) Cavalier, R. R. (1980): Trace elements, in Modern Nutrition in Health and Disease, ed. by Goodhart, R. S., and Shils, M. E., 6th Ed., Lea and Febiger, Philadelphia, pp. 395441.

20) Mitchell, G. V., and Jenkins, M. Y. (1981): Effect of moderate levels of lysine on growth, plasma protein and iron metabolism in casein-fed rats. Fed. Proc., 40, 849.

21) Conley, M. C., and Hathcock, J. N. (1978): Effects of dietary protein and amino acids on iron utilization by iron-depleted rats. J. Nutr., 108, 475-480. 